\title{
VALIDITY OF AN ANALYSIS OF THIN-WALLED HELICOIDAL I-SECTION BEAMS APPROXIMATED BY AN ASSEMBLAGE OF STRAIGHT BEAMS
}

\author{
By Teruhiko YODA*, Hiroyuki FUYAMA** \\ and Masaharu HIRASHIMA***
}

\section{INTRODUCTION}

The increasing use of thin-walled curved and twisted beams has created a need for a simple but thorough analysis of stresses as well as displacements in tortuous members. The spatially curved geometry of such structures, and the complicated flexibility coefficients to be generat$\mathrm{ed}^{1)}$ make the problem very difficult and cumbersome ${ }^{2)}$.

In the ordinary highway bridges, it may be adequate to determine the stresses and displacements by reducing the spatially curved beam to its horizontal projection and then to analyze it as a curved beam. The rigorous treatment of the curved beam becomes so elaborated that it is of little use to the design engineers ${ }^{3), 4), 5 \text { ). }}$.

The difficulties encountered have raised the question of practicability of the space frame analysis for the analysis of a spatially curved beam. For engineering purposes it is preferable to apply the frame analysis that will provide a realistic treatment of the problem to yield valuable information for design use. However, little work has been done to verify the applicability of the space frame analysis to spatially curved beams.

In this paper, an attempt is made to examine the validity of an analysis of thin-walled spatially curved beams approximated by an assemblage of straight beams.

In the first place, the approximate solution on a straight-beam assemblage is compared with the

* Member of JSCE, Dr. of Eng., Associate Professor, Dept. of Civil Engineering, Waseda University

** Member of JSCE, M. of Eng., Mitsubishi Heavy Industries

*** Member of JSCE, Dr. of Eng., Professor, Dept. of Civil Engineering, Waseda University analytically exact solution obtained using the procedure reducing characteristic equations of governing differential equations to eigenvalue equations. The validity of the straight-beam element approximation is confirmed numerically for the I-sectioned thin-walled helicoidal beam with fixed ends, subtending a horizontal angle of 89.5 degrees, and having a slope of 6 degrees.

Secondly, the convergence of the solution on the straight-beam assemblage to that of the originally curved beam is examined by making use of convergence of stiffness equations to the governing equations at the limit of increasing the number of straight-beam elements. The resulting differential equations do not coincide with the exact governing equations. It turned out, however, that the discrepancy is numerically negligible in the commonly encountered spatially curved beams.

\section{EXACT SOLUTION OF GOVERNING EQUILIBRIUM EQUATIONS}

Equilibrium equations for a thin-walled helicoidal beam have the following form when the curvature $k_{2}$ in $y_{3}-y_{1}$ plane equals to zero ${ }^{2)}$.

$$
\begin{aligned}
& N_{, 1}+k_{3} M_{3,1}+h k_{3} M_{2}=-q_{1}-k_{3} m_{3}, \cdots \cdots(1 \cdot \mathrm{a}) \\
& M_{3,11}-h^{2} M_{3}+2 h M_{2,1}+h k_{3} M_{1}-k_{3} N \\
& \quad=q_{2}-m_{3,1}-h m_{2}, \cdots \cdots \cdots \cdots \cdots \cdots \cdots(1 \cdot \mathrm{b}) \\
& \quad \begin{array}{l}
M_{2,11}-h^{2} M_{2}-2 h M_{3,1}+k_{3} M_{1,1} \\
\quad=-q_{3}-m_{2,1}+h m_{3}, \cdots \cdots \cdots \cdots \cdots \cdots(1 \cdot \mathrm{c})
\end{array} \\
& M_{1,1}-k_{3} M_{2}=-m_{1}, \cdots \cdots \cdots \cdots \cdots \cdots \cdots \cdots(1 \cdot \mathrm{d})
\end{aligned}
$$

where

$N$ : axial force,

$M_{i}$ : moment with respect to $y_{i}$-axis,

$q_{i}$ : distributed load on $y_{i}$-axis,

$m_{i}$ : distributed moment with respect to $y_{i}$-axis,

$k_{3}$ : curvature of beam-axis in $y_{1}-y_{2}$ plane,

$h$ : twist of beam-axis $(h=\sin \phi \cos \phi / R$, $\phi$ : pitch-angle), 


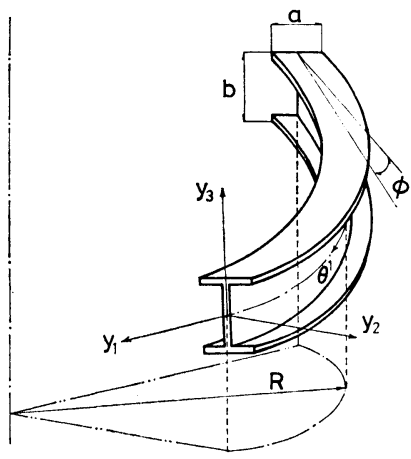

Fig. 1 General View of a Helicoidal Beam and Coordinate Systems.

$R$ : radius of curvature of plane curve,

$y_{i}$ : local right-handed Cartesian coordinates $(i=1,2,3)$,

()$_{11}$ : differentiation with respect to $\theta^{1}$ in the direction of beam-axis.

In view of the smallness of twist, normal stress $\sigma^{11}$ and stress resultants are given by ${ }^{5), 7), 8}$

$$
\begin{aligned}
& \sigma^{11}=\frac{E}{1-k_{3} y_{2}}\left(\varepsilon-y_{2} \chi_{3}+y_{3} \chi_{2}+\omega \chi_{1,1}\right), \\
& N=E A \varepsilon-E J \nu_{2} \chi_{3}+E J \nu_{3} \chi_{2}, \\
& M_{2}=E J \nu_{3} \varepsilon-E J \nu_{2} \nu_{3} \chi_{3}+E J \nu_{3} \nu_{3} \chi_{2} \\
& +E J_{\omega y_{3}} \chi_{1,1} \text {, } \\
& M_{3}=-E J \nu_{2} \varepsilon+E J \nu_{2} \nu_{2} \chi_{3}-E J \nu_{2} \nu_{3} \chi_{2} \\
& -E J_{\omega \gamma_{2}} \chi_{1,1} \text {, } \\
& M_{\omega}=E J_{\omega \nu_{2}} \chi_{3}-E J_{\omega \nu_{3}} \chi_{2}-E J_{\omega \omega} \chi_{1,1}, \cdots(3 \cdot \mathrm{d}) \\
& T=G J_{T D} \chi_{1} \\
& M_{1}=M_{\omega, 1}+T \text {, } \\
& Q_{2}=-M_{3,1}-h M_{2} \text {, } \\
& Q_{3}=M_{2,1}-h M_{3}+k_{3} M_{1} \text {, }
\end{aligned}
$$

in which

$$
\begin{aligned}
& \varepsilon=u^{1}, 1-k_{3} u^{2}, \\
& \chi_{1}=\vartheta, \ldots \\
& \chi_{2}=\Phi, k_{, 1}+h \Psi-k_{3} \vartheta \\
& \chi_{8}=\Psi_{, 1}-h \Phi \\
& \Phi=-u^{3},{ }_{1}-h u^{2}, \\
& \Psi=u^{2}, \ldots \\
& { }_{1}-h u^{3}+k_{3} u^{1}
\end{aligned}
$$

where

$\omega$ : sectorial area,

$M_{\omega}$ : bimoment,

$T$ : St. Venant's torsion moment,

$Q_{i}$ : shearing force in the direction of $y_{i}$ axis $(i=2,3)$,

$E$ : Young's modulus,

$G$ : shear modulus,

$A$ : cross-sectional area,

$J_{y_{i}}$ : geometrical moment of area $(i=2,3)$,
$J_{y_{i} y_{i}}:$ geometrical moment of inertia $(i=2,3)$,

$J v_{2} y_{3}$ : product of inertia of area,

$J_{\omega y_{i}}$ : sectorial product of intertia $(i=2,3)$,

$J_{\omega \omega}$ : sectorial moment of inertia,

$J_{T D}:$ pure torsional constant,

$\varepsilon$ : axial strain,

$\chi_{i}$ : rate of rotation angle about $y_{i}$-axis $(i=1,2,3)$,

$\Phi$ : rotation angle with respect to $y_{2}$-axis,

$\Psi$ : rotation angle with respect to $y_{3}$-axis,

$\vartheta$ : rotation angle with respect to $y_{1 \text {-axis, }}$

$u^{i}$ : displacement in the direction of $y_{i}$-axis $(i=1,2,3)$.

Therefore, the stress resultants can be eliminated from Eqs. (1) to (4), where no distributed load is applied. Equilibrium equations with mutually independent displacements $u^{1}, u^{2}, u^{3}, \vartheta$ result in

$$
\begin{aligned}
& a_{1} u^{1}, 11+a_{2} u^{1}, 1+a_{3} u^{1} \\
& \quad+a_{4} u^{2},{ }_{111}+a_{5} u^{2}, 11+a_{6} u^{2},{ }_{1}+a_{7} u^{2} \\
& \quad+a_{8} u^{3},{ }_{111}+a_{9} u^{3},{ }_{11}+a_{10} u^{3}, 1+a_{11} u^{8} \\
& \quad+a_{12} \vartheta,{ }_{111}+a_{13} \vartheta,{ }_{11}+a_{14} \vartheta,{ }_{11}+a_{15} \vartheta=0
\end{aligned}
$$

$$
\begin{aligned}
& b_{1} u^{1}, 111+b_{2} u^{1}, 11+b_{3} u^{1}, 1+b_{4} u^{1} \\
& +b_{5} u^{2}{ }_{1111}+b_{6} u^{2},{ }_{111}+b_{7} u^{2}{ }_{111}+b_{8} u^{2}{ }^{2}+b_{9} u^{2} \\
& +b_{10} u^{3}{ }_{1111}+b_{11} u^{3}{ }_{, 111}+b_{12} u^{3}{ }_{11}+b_{13} u^{3}{ }_{, 1}+b_{14} u^{3} \\
& +b_{15 \vartheta},_{1111}+b_{16,} \vartheta_{111}+b_{17} \vartheta_{, 11}+b_{18} \vartheta, 1+b_{19} \vartheta \\
& =0 \text {, } \\
& c_{1} u^{1,111}+c_{2} u^{1}, 11+c_{3} u^{1}, 1+c_{4} u^{1} \\
& +c_{5} u^{2}, 1111+c_{6} u^{2}, 111+c_{7} u^{2}, 11+c_{8} u^{2}, 1+c_{9} u^{2} \\
& +c_{10} u^{3}{ }_{1111}+c_{11} u^{3}{ }_{, 111}+c_{12} u^{3}{ }_{, 11}+c_{18} u^{3}{ }_{11}+c_{14} u^{3} \\
& +c_{15} \vartheta,{ }_{1111}+c_{16} \vartheta, 111+c_{17} \vartheta,{ }_{11}+c_{18} \vartheta, 1+c_{19} \vartheta \text {. } \\
& =0 \text {, } \\
& d_{1} u^{1}, 111+d_{2} u^{1}, 11+d_{8} u^{1}, 1+d_{4} u^{1} \\
& +d_{5} u^{2}{ }_{, 1111}+d_{8} u^{2},{ }_{111}+d_{7} u^{2},{ }_{11}+d_{8} u^{2}{ }_{, 1}+d_{9} u^{2} \\
& +d_{10} u^{3}{ }_{, 111}+d_{11} u^{3}, 111+d_{12} u^{3}{ }_{11}+d_{13} u^{3}{ }_{, 1}+d_{14} u^{8} \\
& +d_{15} \vartheta,{ }_{1111}+d_{16} \vartheta,{ }_{111}+d_{17} \vartheta, 11+d_{18} \vartheta, 1+d_{19} \vartheta \\
& =0 \text {, }
\end{aligned}
$$

where $a_{j}(j=1, \sim, 15), b_{k}, c_{k}, d_{k}(k=1, \sim, 19)$ are constants, including $k_{3}, h, E, G$ and crosssectional properties. Some of the constants are written as

$$
\begin{aligned}
& a_{1}=E A-2 k_{3} E J y_{2}+k_{3}{ }^{2} E J y_{2} y_{2}, \\
& a_{2}=-2 h k_{3}{ }^{2} E J v_{2} v_{3} \text {, } \\
& a_{8}=h^{2} k_{8}{ }^{2} E J v_{3} y_{3} \text {, } \\
& a_{4}=-E J v_{2}+k_{3} E J v_{2} \nu_{2} \text {, } \\
& a_{5}=-2 h E J \nu_{3}+h k_{3} E J v_{\nu_{2} \nu_{2}}-h k_{3}{ }^{2} E J \omega \nu_{2} \text {. }
\end{aligned}
$$

In order to solve Eq. (5), the following types of solutions are employed: 


$$
\begin{aligned}
u^{2} & =\tilde{A} \exp \left\{\lambda \theta^{1}\right\}, \\
u^{3} & =\tilde{B} \exp \left\{\lambda \theta^{1}\right\}, \\
u^{1} & =\tilde{C} \exp \left\{\lambda \theta^{1}\right\}, \\
\vartheta & =\tilde{D} \exp \left\{\lambda \theta^{1}\right\},
\end{aligned}
$$

Introduction of Eq. (7) to Eq. (5) yields

$$
\begin{aligned}
& f_{1.1} \tilde{A}+f_{1.2} \tilde{B}+f_{1.3} \tilde{C}+f_{1.4} \tilde{D}=0, \\
& f_{2.1} \tilde{A}+f_{2.2} \tilde{B}+f_{2.3} \tilde{C}+f_{2.4} \tilde{D}=0, \\
& f_{3.1} \tilde{A}+f_{3.2} \tilde{B}+f_{3.3} \tilde{C}+f_{3.4} \tilde{D}=0, \\
& f_{4.1} \tilde{A}+f_{4.2} \tilde{B}+f_{4.3} \tilde{C}+f_{4.4} \tilde{D}=0,
\end{aligned}
$$

where $f_{i . j}$ are constants including $\lambda$. Some of the $f_{i, j}$ are written as

$$
\begin{aligned}
& f_{1.3}=a_{1} \lambda^{2}+a_{2} \lambda+a_{3}, \\
& f_{2.3}=b_{1} \lambda^{3}+b_{2} \lambda^{2}+b_{3} \lambda+b_{4}, \\
& f_{3.3}=c_{1} \lambda^{3}+c_{2} \lambda^{2}+c_{3} \lambda+c_{4}, \\
& f_{4.3}=d_{1} \lambda^{3}+d_{2} \lambda^{2}+d_{3} \lambda+d_{4} .
\end{aligned}
$$

The following constants are introduced to solve the characteristic equations as the eigenvalue equations ${ }^{6}$.

$$
\begin{aligned}
& \tilde{E}=\tilde{A} \lambda, \quad \tilde{I}=\tilde{E} \lambda, \quad \tilde{L}=\tilde{I} \lambda, \\
& \tilde{F}=\tilde{B} \lambda, \quad \tilde{J}=\tilde{F} \lambda, \quad \tilde{M}=\tilde{J} \lambda, \\
& (10 \cdot a, b, c) \\
& \tilde{G}=\tilde{C} \lambda \text {, } \\
& (10 \cdot d, e, f) \\
& \tilde{H}=\tilde{D} \lambda, \quad \tilde{K}=\tilde{H} \lambda, \quad \tilde{N}=\tilde{K} \lambda
\end{aligned}
$$

These procedures involve reduction of Eq. (8) to the standard eigenvalue problem:

$$
\left[k_{m \cdot n}\right]\{\boldsymbol{r}\}=\lambda\{\boldsymbol{r}\},
$$

where $\{\boldsymbol{r}\}^{T}=\{\tilde{A}, \tilde{B}, \cdots, \tilde{N}\}$ and $k_{m \cdot n}(m=1, \sim, 4$; $n=1, \sim, 14)$ are constants including $a_{j}(j=1, \sim$, 15), $\quad b_{k}, c_{k}$ and $d_{k}(k=1, \sim, 19)$. Then characteristic solutions are obtained as eigenvalues. The relation among coefficients of $u^{1}, u^{2}, u^{3}, \vartheta$ is determined from the eigenvectors $\tilde{A}, \cdots, \tilde{D}$, and other eigenvectors such as $\tilde{E}, \cdots, \tilde{N}$ are apparently of no use. In this paper, the eigenvalue problems arising in the analysis were solved by standard library subroutines (MSL II at the Computer Center of University of Tokyo).

Hence, after appropriate boundary conditions have been introduced, Eq. (5) can be solved to yield the exact displacements, stress resultants and stresses.

It should be noted that the present solution procedure is applicable to the general case of helicoidal beams with initial curvature $k_{2}, k_{3}$ and initial twist $h$ without any difficulty.

\section{STRAIGHT-BEAM ELEMENT APPROXI- MATION}

The simplest method of analyzing a thin-walled spatially curved beam is based on approximating the beam by a series of straight-beam elements including the warping contribution. The direct stiffness method is used to obtain displacements and stresses for the approximate model represented by an assemblage of thin-walled straightbeam elements.

No distributed loads will be considered and centroid-axis can be taken as the beam-axis in the thin-walled straight beams with doublysymmetric section. Deformations of the beams are known to be governed by the differential equations $^{9)}$ :

$$
\begin{aligned}
& E \dot{A} u^{1}{ }_{11}=0 \text {, } \\
& E \dot{J}_{y_{2} y_{2}} u^{2}, 1111=0 \text {, } \\
& E \dot{J}_{y_{3} v_{3}} u^{3}, 1111=0 \text {, } \\
& E \dot{J}_{\omega \omega} \vartheta,_{1111}-G \dot{J}_{T D} \vartheta,_{11}=0 \text {, }
\end{aligned}
$$

where $\left({ }^{\cdot}\right)$ denotes the cross-sectional properties of the corresponding straight-beam elements.

The resulting stiffness matrix of a beam element is exact due to the utilization of shape functions which are derived from the solutions of the homogeneous differential equations. Once the stiffness matrix has been developed for individual beam elements, they are assembled by transformations to yield the corresponding global matrix in the reference coordinates. The transformations in this paper are functioned to each of element stiffness matrix such that $y_{2}$-axis is always parallel to horizontal plane in the cylindrical coordinates of the helicoidal beam. As a result, twist is introduced in the straight-beam assemblage approximately.

Accordingly, the standard techniques for the space frame analysis lead to approximate solutions on the straight-beam assemblage, including the warping contribution.

\section{COMPARISON OF EXACT SOLUTION AND APPROXIMATE SOLUTION}

The model shown in Fig. 2 is used for the numerical analysis. The helicoidal beam with fixed ends has doubly symmetric thin-walled Isection, subtending a horizontal angle of 89.5 degrees, and having a slope of 6 degrees.

Figures 3 and 4 show the relationships between cross-sectional properties and radius of curvature

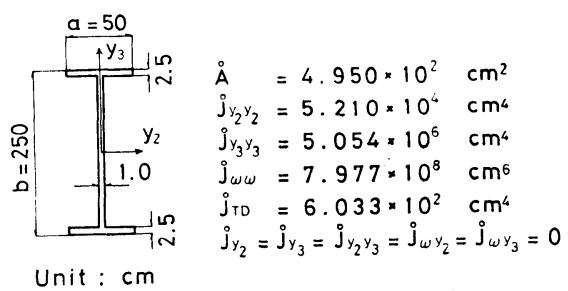

Fig. 2 Cross-Sectional Properties. 


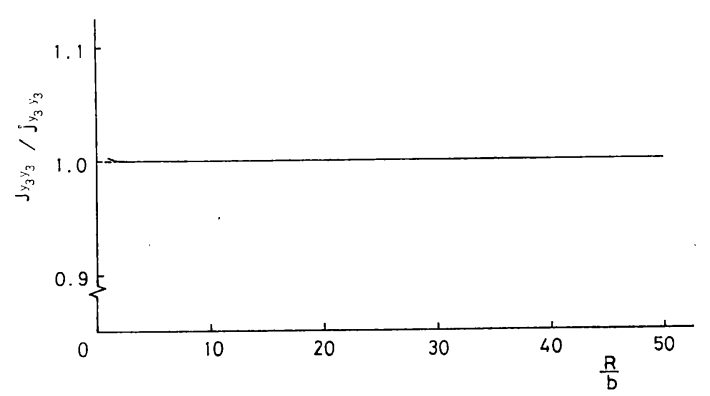

Fig. 3 Relationship between $J y_{3} y_{3} / \dot{J}_{y_{3} y_{3}}$ and $R / b$.

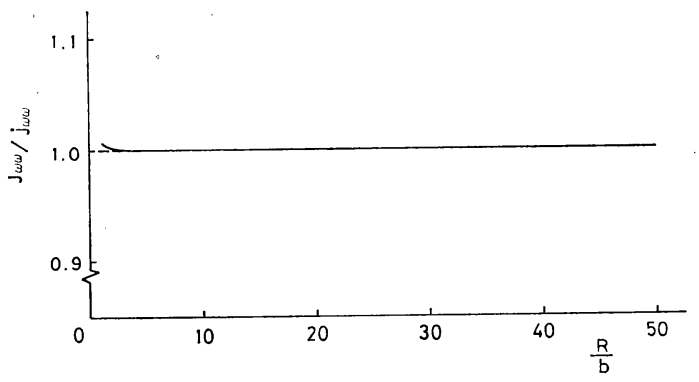

Fig. 4 Relationship between $J_{\omega \omega} / \dot{J}_{\omega \omega}$ and $R / b$.

$R$, in which centroid-axis is taken as the beamaxis. It follows from the numerical study that the effect of curvature $R$ is not reflected in crosssectional properties of the ordinary spatially curved beams.

The variations in the errors of the approximate solutions with the number of beam elements are shown in Figs. 5 and 6, in which and in what follows, the following basic data are used: $l=$ $62.83 \mathrm{~m}, \quad R=40.00 \mathrm{~m}, \quad E=2.1 \times 10^{6} \mathrm{~kg} / \mathrm{cm}^{2} \quad(206$ $\mathrm{GPa})$, and $G=0.81 \times 10^{6} \mathrm{~kg} / \mathrm{cm}^{2}(79 \mathrm{GPa})$. It will be observed that the approximate solutions converge to exact ones as the number of elements increases, and that 10 -element solutions provide sufficient approximations, in which ( $)_{A}$ and ( ) $\boldsymbol{E}$ denote approximate and exact solutions respectively.

To ensure whether the present approximate solutions are well behaved or not, vertical shearing force $98 \mathrm{~N}(Q=-97.46 \mathrm{~N}, N=10.24 \mathrm{~N})$ is loaded on the centroid of the section at the center of the beam. Several general patterns of static behavior can readily be observed in Figs. $7, \sim$, 11 , in which the longitude indicates the value of displacements (or normal stress), and the latitude indicates the distance from the origin of $\theta^{1}$. The solid lines denote the exact solutions and the plots the approximate ones. Excellent correlation is observed; 10-element approximation seems to give sufficient solutions at large. The results of computer analysis confirmed this in all cases.

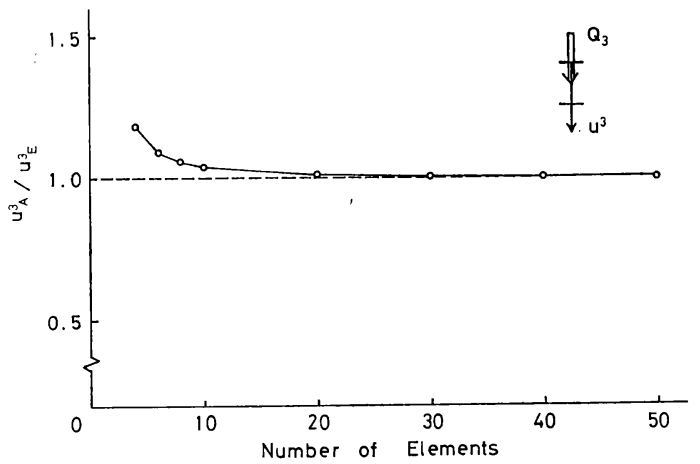

Fig. 5 Convergence of $u^{3}$ (Due to $Q_{3}$ ).

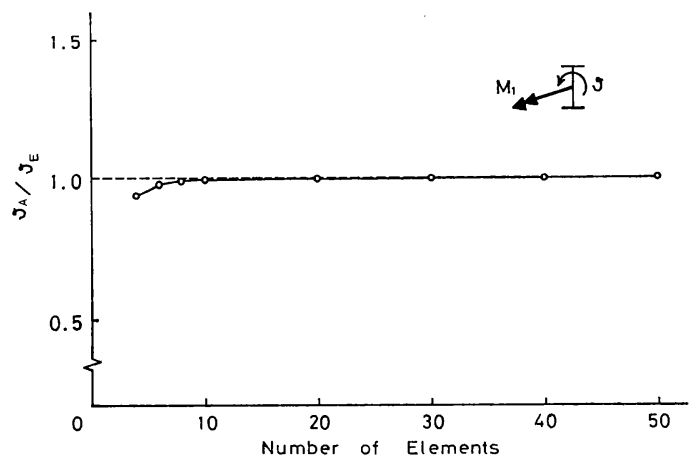

Fig. 6 Convergence of $\vartheta$ (Due to $M_{1}$ ).

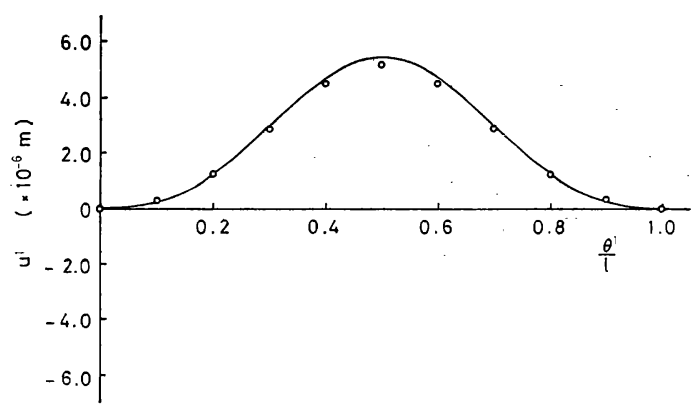

Fig. $7 u^{1}$ Due to Vertical Load.

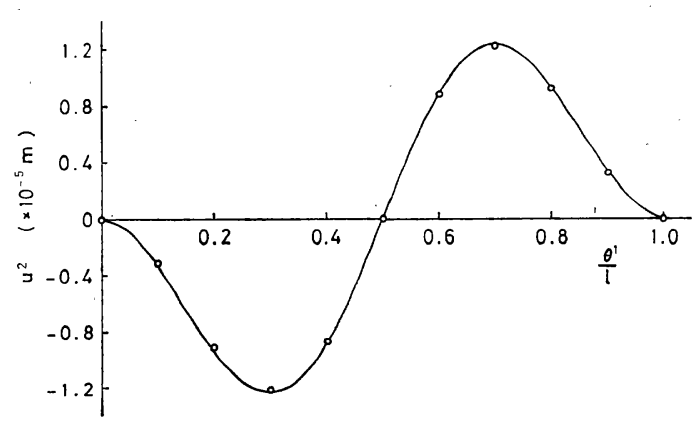

Fig. $8 \iota^{2}$ Due to Vertical Load. 


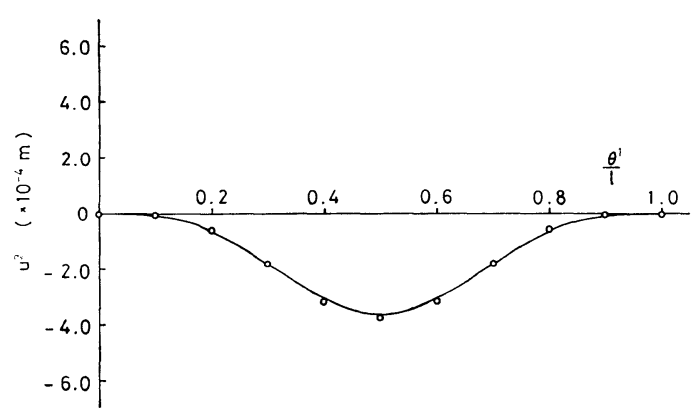

Fig. $9 u^{3}$ Due to Vertical Load.

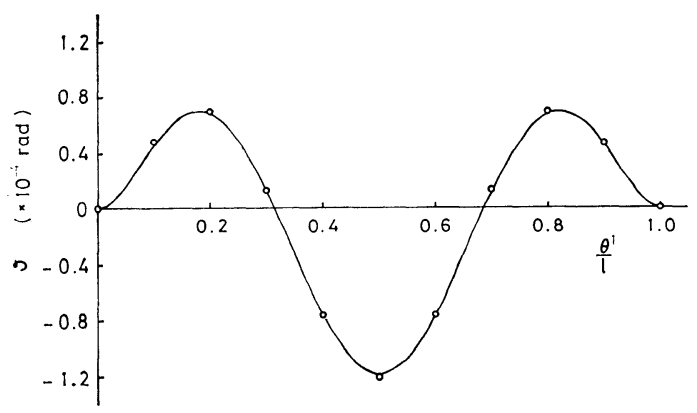

Fig. $10 \vartheta$ Due to Vertical Load.

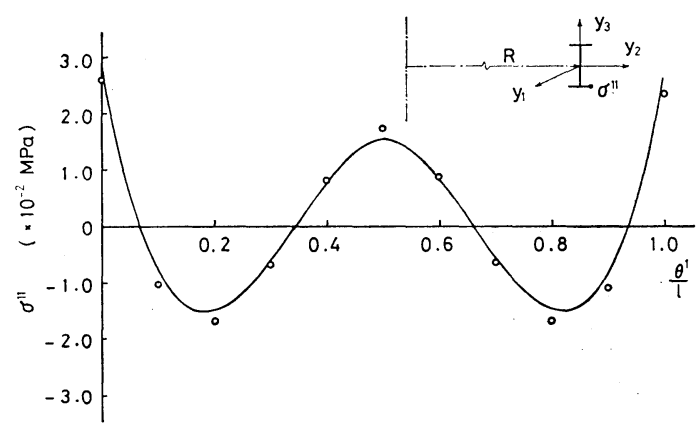

Fig. 11 Stress $\sigma^{11}$ Due to Vertical Load.

A more complete range of figures has been developed and presented in Ref. 10).

\section{DISCUSSION}

The foregoing straight line approximation by an assemblage of straight beams has been shown to predict satisfactorily the static behavior of a spatially curved beam. The approximate analysis involves the generation of the exact stiffness matrix for a thin-walled straight beam, including the warping contribution. Once this step is performed, the analysis proceeds in an analogous way to that followed in any thinwalled spatially curved beam by the stiffness matrix. Accordingly, this approximation can be applied to usual thin-walled spatially curved beams with open and/or closed section by dividing the total span into many segments and treating each one as a different thin-walled straight beam.

In view of these facts, it will be imagined that the pertinent approximation of a spatially curved beam is the limiting case of a beam consisting of straight-beam elements whose length tends to zero. Therefore, consideration should be placed on determining how closely the straight-beam assemblage must approximate the spatially curved beam in order to provide accurate solutions to the problem of stress and deflection analysis. To this end it is necessary to verify the consistency with the exact governing equations of the problem, which is an important aspect to be checked.

The first step towards the realization of this solution process is the following development of the limiting case of a beam consisting of straightbeam elements. Consider three successive nodes of a straight-beam element assemblage. Coordinate transformations are made to satisfy the continuity of nodal forces and nodal displacements at the center node, in which the pointwise reference coordinates at the node are chosen so as to coincide with the local Cartesian coordinates of the spatially curved beam. When no distributed load is considered at the center node, governing equations are obtained using the adjacent element stiffness matrices ${ }^{4}$. Expanding adjacent generalized nodal displacement vectors in a Taylor's series at the center point and rearranging the governing equations regarding power series of the element length yield governing equations characterized by seven generalized nodal displacements. The reduction of the governing equations gives four governing differential equations at the limit of increasing the number of straight beam elements. The resulting governing equations are similar in form to the exact governing equations given by Eq. (5) but slightly differ in their coefficients. Nevertheless, it appears from the present numerical evaluation that the difference is assumed small enough to be ignored in the calculation of displacements and stresses for ordinary spatially curved beams.

For the explicit comparison's sake, consider a case of a horizontally curved beam with doubly. symmetric section. The approximate governing differential equations for the curved beam become

$$
\begin{aligned}
& E \dot{A} u^{1},{ }_{11}-k_{3} E \dot{J}_{y_{2} y_{2}} u^{2}{ }_{, 111}-k_{3} E \dot{A} u^{2}{ }_{, 1}=0 \text {, } \\
& k_{3} E \dot{J}_{y_{2} \nu_{2}} u^{1,111}-\left\{k_{3} E \dot{A}-k_{3}{ }^{3} E \dot{J}_{y_{2} y_{2}}\right\} u^{1}, 1 \\
& +E \dot{J}_{v_{2} y_{2}} u^{2}, 1111+k_{3}{ }^{2} E A u^{2}=0 \text {, }
\end{aligned}
$$




$$
\begin{aligned}
& -E \dot{J}_{y_{3} y_{3}} u^{3}{ }^{31111}+k_{3}{ }^{2} G \dot{J}_{T D} u^{3}{ }^{11}-k_{3} E \dot{J}_{\omega \omega} \vartheta, 1111 \\
& +\left\{k_{3} E \dot{J}_{y_{3} y_{3}}+k_{3} G \dot{J}_{T D}\right\} \vartheta_{, 11}=0, \cdots \cdots(13 \cdot \mathrm{c}) \\
& -k_{3} E \dot{J}_{\omega \omega} u^{3}, 1111 \\
& +\left\{k_{3} E \dot{J}_{y_{3} y_{3}}+k_{3} G \dot{J}_{T D}-k_{3}{ }^{3} E \dot{J}_{\omega \omega}\right\} u^{3}{ }_{, 11} \\
& -E \dot{J}_{\omega \omega} \vartheta{ }_{, 111}+G \dot{J}_{T D} \vartheta{ }_{, 11}-k_{3}{ }^{2} E \dot{J}_{y_{3} y_{3}} \vartheta \\
& =0 \text {. }
\end{aligned}
$$

On the other hand, the exact governing differential equations of the curved beam can be written as, in view of Eq. (5),

$$
\begin{aligned}
& \left\{E A+k_{3}^{2} E J y_{2} y_{2}\right\} u^{1}, 11-k_{3} E J y_{2} y_{2} u^{2}, 111 \\
& -k_{3} E A u^{2}, 1=0 \\
& k_{3} E J v_{2} y_{2} u^{1}, 111-k_{3} E A u^{1}, 1+E J \nu_{2} \nu_{2} u^{2}{ }^{2}, 111 \\
& +k_{3}{ }^{2} E A u^{2}=0 \text {, } \\
& -\left\{E J y_{3} y_{3}+k_{3}{ }^{2} E J_{\omega \omega}\right\} u^{3}, 1111+k_{3}{ }^{2} G J_{T D} u^{3}, 11 \\
& -k_{3} E J_{\omega \omega} \vartheta, 1111+\left\{k_{3} E J y_{3} y_{3}+k_{3} G J_{T D}\right\} \vartheta, 11 \\
& =0 \text {, } \\
& -k_{3} E J_{\omega \omega} u^{3}, 1111+\left\{k_{3} E J \nu_{3} \nu_{3}+k_{3} G J_{T D}\right\} u^{3}, 11 \\
& -E J_{\omega \omega} \vartheta, 1111+G J_{T D} \vartheta,_{11}-k_{3}^{2} E J_{\nu_{3} y_{3}} \vartheta \\
& =0 \text {, }
\end{aligned}
$$

As can be expected, the difference of crosssectional properties is evident. However, the difference has little effect on the calculated values as mentioned in Chapter 4. Consequently, cross-sectional properties of the curved beam are conveniently treated in terms of those of the corresponding straight beam. Another difference will be observed for the coefficients of the governing equations as indicated by underlines in Eqs. (13) and (14). The only conclusion possible is that the inequalities $E A>k_{3}{ }^{2} E J \nu_{2} y_{2}$ and $E J y_{3} y_{3}$ $>k_{3}{ }^{2} E J_{\omega \omega}$ play a key role in the approximate analysis, and thus the approximate analysis is valid for $E A \gg k_{3}{ }^{2} E J v_{2} y_{2}$ and $E J \nu_{3} \nu_{3} \gg k_{3}{ }^{2} E J \omega \omega$; for example, $E A=1.02 \times 10^{10} \mathrm{~N}, \quad k_{3}{ }^{2} E J \nu_{2} y_{2}=0.67$ $\times 10^{5} \mathrm{~N}$ as for $E A \gg k_{3}{ }^{2} E J y_{2} y_{2}$ and $E J y_{3} y_{3}=1.04 \times$ $10^{14} \mathrm{~N}, k_{3}{ }^{2} E J \omega \omega=1.03 \times 10^{9} \mathrm{~N}$ as for $E J y_{3} v_{3} \gg k_{3}{ }^{2}$. $E J_{\omega \omega}$ in the helicoidal I-section beam shown in Fig. 2. For the present comparison and the foregoing evaluation, it is apparent that approximate values are better predicted by the approximate analysis, since most curved beams satisfy the aforementioned inequalities. This statement is also supported by the evidence as shown in Figs. 7, , 11 .

\section{CONCLUDING REMARKS}

A technique of an approximate analysis of thin-walled spatially curved beams by an assemblage of straight beam elements appears justified and gives favorable results compared with analytically exact solutions. It is concluded that the present straight-beam approximation provides a practical tool for the analysis of arbitrary spatially curved beam, and that the space frame analysis of a spatially curved beam is considered to be valid for design purposes in that excellent accuracy is observed for both displacements and stresses.

The authors wish to express their deepest appreciation to Dr. M. Iura, Tokyo-Denki University for the valuable suggestions.

Finally, the use of the computing facilities at the Computer Center of University of Tokyo (HITAC M-200H) is gratefully acknowledged.

\section{REFERENCES}

1) Nishino, F. and Y. Fukazawa: Formulation of static behavior of thin-walled curved beams under assumptions of strain field, Proceedings of JSCE, No. 247, pp. 9〜19, May 1976 (in Japanese).

2) Hirashima, M. and S. Eya: Fundamental theory of thin-walled helical beams with open section, Proceedings of JSCE, No. 281, pp. 1 9, Jan. 1979 (in Japanese).

3) Usuki, S. and T. Kano: Analysis of thin walled curved beams by stiffness method, Proceedings of JSCE, No. 235, pp. 29 39, March 1975 (in (Japanese).

4) Suzuki, T., S. Ueno and F. Nishino: Analysis of circular members by an assemblage of straight elements, Proceedings of the 26th Structural Engineering Symposium, pp. 121 132, Feb. 1980 (in Japanese).

5) Fuyama, H., T. Yoda and M. Hirashima: Analysis of thin-walled curved beams by an assemblage of straight beam elements, Proceedings of the 31st Japan National Congress for Applied Mechanics, pp. 169 170, Nov. 1981 (in Japanese).

6) Iura, M.: Fourier analysis of unclosed conical shells with linearly varying thickness, Proceedings of the 1981 Annual Conference of the Architectural Institute of Japan, pp. 1153 1154, Sept. 1981 (in Japanese).

7) Tsuiji, T.: Fundamental equations of curved and twisted beams, Proceedings of JSCE, No. 230, pp. $11 \sim 21$, Oct. 1974 (in Japanese).

8) Tsuiji, T.: Deflection analysis of thin-walled open section helical beams, Proceedings of JSCE, No. 236, pp. 31 45, April 1975 (in Japanese).

9) Vlasov, V. Z.: Thin-Walled Elastic Beams, Israel Program for Scientific Translations, Ierusalem, p. 40, 1961.

10) Fuyama, H., M. Hirashima and T. Yoda: Analysis of thin-walled helicoidal beams using physical approximation, Proceedings of the 28th Structural Engineering Symposium, pp. 39 49, Feb. 1982 (in Japanese).

(Received July 29, 1982) 
土木学会論文報告集 第 335 号

\section{折れ線近似による薄肉 I 形断面 ら旋ばりの解析の妥当性}

（依田照彦／布山裕之／平掝政治）
通常，薄肉空間曲線ばりの設計においては，空間曲線 ばりを直線ばりの集合に置き換えるという手法が用いら れている.しかしながら，火の得られた数值解が妥当で あるかどうかについては，いまだに吟味されないままで ある. 本研究では，この折れ線近似による解析の妥当性 を，I 形断面をもつ薄肉ら旋ばりを例にとり，検討した。

既往の研究によれば, 薄肉ら旋ばりの変位成分表示の つり合い式は, 4 元 14 階の連立定数係数微分方程式とな る.ここでは, 微分方程式の特性方程式が高次代数方程 式になる点に着目し，特性方程式を固有值方程式に変換 し, 特性根を固有値として求め, さらに, 固有べクトル を用いて係数間の関係式を求めた，すなわち，固有值問 題を介して, つり合い式の厳密解を求めた.

また，折れ線近似による解析では，直線ばりの主座標 系に拉けるつり合い式を用いて, 直接的に要素剛性マト リックスを誘導し，そり変形の影響を含む標準的な立体 骨組解析の手法を用いて, 薄肉ら旋ばりの变位と応力を 求めた。そ際，個々の要素剛性マトリックスを，ら旋 ばりの円柱座標系に沿って座標変換させ, 全体剛性マト リックスを作成した。このことにより，近似的に部材軸 のねじれ率が折れ線近似モデルに導入された。

以上のようにして得られた㛜密解と近似解を基礎に, 部材長 $62.83 \mathrm{~m}$, 平面曲線半径 $40 \mathrm{~m}$, ピッチ角 $6^{\circ}$ (縦 断勾配 $10.5 \%$ ）の両端固定 I 形断面ら旋ばりを使用して 数值計算を行った，その結果，本研究で使用したら旋ば りの断面定数は同じ断面寸法をもつ直線ばりの断面定数 とほぼ一致すること，および，両端固定ら旋ばりの場合 でも10要素の折れ線近似モデルで妥当な近似解が得られ ることがわかった，さらに，折れ線近似モデルが薄肉ら 旋ばりの静力学的挙動をとらえているかどうかを調べる
ため，両端固定ばりの中央点の図心に鉛直荷重を載荷さ せ，そのときの変位と応力を計算し，これらの近似解が 厳密解とよく一致していることを確認した.

さらに，折れ線近似解析の妥当性を理論的に検証する ため, 折れ線近似モデルの解が，折れ線の要素数を増加 させたときに，厳密解に収束するかどうかを，陽な形の 支配方程式で比較することを試みた。すなわち，折れ線 近似モデルの中で，外力の作用していない節点に注目す れば，その節点に打ける支配方程式は，折れ線近似モデ ルの基準座標系をら旋ばりの部材軸方向座標系と一致さ せることにより，節点を共有する隣接要素の剛性方程式 を用いて作成することができる，そこで，節点変位べク トルを，その節点回りで Taylor 展開し，直ばり要素の 部材長のべき乗の順に各支配方程式を整理し，さらに， 式の縮約を行い，要素分割数を無限大にすると，4 個の 独立な支配方程式が得られる。

このようにして得られた 4 個の支配方程式と薄肉ら旋 ばりの支配方程式とを比較すると，断面定数および微分 方程式の係数に差異は認められるものの，主たる項は一 致することがわかった．ここでは，陽な形での支配方程 式の比較を考え，薄肉 I 形断面円弧ばりの支配方程式を 具体的に提示し，折れ線近似解析の有効範囲を明確にし た.

本研究で得られた結論のおすなものを列記すれば，以 下のようである。

（1）薄肉ら旋ばりの支配方程式の厳密解は，固有値問 題を介して，容易に求められる.

(2) そり変形を考虑した折れ線近似解析を用いること により，任意の薄肉空間曲線ばりの近似解析が可能とな る.

(3) 折れ線近似による薄肉空間曲線ばりの解析の妥当 性は，ねじれ率が小さく，不等式

$$
E A \gg k_{3}^{2} E J v_{2} y_{2} ; E J \nu_{3} y_{3} \gg k_{3}^{2} E J \omega \omega
$$

が成り立つ場合に保証される。ただし， $k_{3}$ ：曲率， $E A$ : 軸剛性, $E J y_{2} y_{2}$ : 曲率面内曲げ剛性, $E J y_{3} y_{3}$ : 曲害面外 曲げ剛性, $E J_{\omega \omega}$ ：そり剛性，である。

（4）通常の薄肉空間曲線ばりでは，上記 (3) の条件が すべて満たされているので，折れ線近似による解析が有 効である. 